\title{
Molluscan Models in Evolutionary Biology: Apple Snails (Gastropoda: Ampullariidae) as a System for Addressing Fundamental Questions
}

\author{
Author(s): Kenneth A. Hayes, Robert H. Cowie, Aslak Jørgensen, Roland Schultheiß, Christian
} Albrecht, and Silvana C. Thiengo

Source: American Malacological Bulletin, 27(1/2):47-58.

Published By: American Malacological Society

https://doi.org/10.4003/006.027.0204

URL: http://www.bioone.org/doi/full/10.4003/006.027.0204

BioOne (www.bioone.org) is a nonprofit, online aggregation of core research in the biological, ecological, and environmental sciences. BioOne provides a sustainable online platform for over 170 journals and books published by nonprofit societies, associations, museums, institutions, and presses.

Your use of this PDF, the BioOne Web site, and all posted and associated content indicates your acceptance of BioOne's Terms of Use, available at www.bioone.org/page/terms_of_use.

Usage of BioOne content is strictly limited to personal, educational, and non-commercial use. Commercial inquiries or rights and permissions requests should be directed to the individual publisher as copyright holder. 


\title{
Molluscan models in evolutionary biology: Apple snails (Gastropoda: Ampullariidae) as a system for addressing fundamental questions ${ }^{\star}$
}

\author{
Kenneth A. Hayes ${ }^{1,2}$, Robert H. Cowie ${ }^{1}$, Aslak Jørgensen ${ }^{3}$, Roland Schulthei ${ }^{4}$, Christian Albrecht ${ }^{4}$, \\ and Silvana $\mathrm{C}$. Thiengo ${ }^{5}$
}

\author{
${ }^{1}$ Center for Conservation Research and Training, Pacific Biosciences Research Center, University of Hawaii, 3050 Maile Way, Honolulu, \\ Hawaii 96822, U.S.A. \\ ${ }^{2}$ Department of Zoology, University of Hawaii, Honolulu, Hawaii 96822, U.S.A. \\ ${ }^{3}$ Mandahl-Barth Research Centre for Biodiversity and Health, DBL-Centre for Health Research and Development, Department of Disease \\ Biology, The Faculty of Life Sciences, University of Copenhagen, Thorvaldsensvej 57, DK-1871 Frederiksberg C, Denmark \\ ${ }^{4}$ Department of Animal Ecology and Systematics, Justus Liebig University Giessen, Heinrich-Buff-Ring 26-32 IFZ, D-35392 Giessen, Germany \\ ${ }^{5}$ Departamento de Malacologia, Instituto Oswaldo Cruz/Fiocruz, Av. Brasil 4365 Manguinhos, 21.040-900, Rio de Janeiro, Brasil \\ Corresponding author: khayes@hawaii.edu
}

\begin{abstract}
Molluscs constitute the second largest phylum in terms of the number of described species and possess a wide array of characteristics and adaptations for living in marine, terrestrial, and freshwater habitats. They are morphologically diverse and appear in the fossil record as far back as the early Cambrian ( 560 mybp). Despite their high diversity and long evolutionary history, molluscs are often underused as models for the study of general aspects of evolutionary biology. Freshwater snails in the family Ampullariidae have a global tropical and subtropical distribution and high diversity with more than 150 species in nine currently recognized genera, making them an ideal group to address questions of historical biogeography and some of the underlying mechanisms of speciation. They exhibit a wide range of morphological, behavioral, and physiological adaptations that have probably played a role in the processes of diversification. Here we review some of the salient aspects of ampullariid evolution and present some early results from ongoing research in order to illustrate the excellent opportunity that this group provides as a system for addressing numerous questions in evolutionary biology, particularly with regard to the generation of biodiversity and its distribution around the globe. Specifically, we suggest that ampullariids have great potential to inform (1) biogeography, both on a global scale and a smaller intra-continental scale, (2) speciation and the generation of biodiversity, through analysis of trophic relations and habitat partitioning, and addressing issues such as Rapoport's Rule and the latitudinal biodiversity gradient, and (3) the evolution of physiological and behavioral adaptations. Also, a number of species in the family have become highly successful invasives, providing unintentional experiments that may offer insights into rapid evolutionary changes that often accompany introductions, as well as illuminating invasion biology in general.
\end{abstract}

Key words: biogeography, speciation, freshwater, Pomacea

Molluscs are second only to arthropods in number of described species, roughly estimated at about 100,000 , with a further 100,000 or so as yet undescribed (Lindberg et al. 2004). Although 60-70\% of molluscs are marine (van Bruggen 1995), they are also well represented in freshwater and terrestrial habitats. Their adaptations in these environments are displayed through a variety of trophic, ecological, and morphological characteristics (Lindberg et al. 2004). Yet despite their high biodiversity and multifaceted life histories and habits, molluscs remain underused in addressing general aspects of evolutionary biology. Several features of the group, including its long history, global distribution, ecological and morphological diversity, and high biodiversity, make it amenable to providing fundamental insights into many evolutionary issues, including patterns of historical biogeography, mechanisms generating biodiversity, and the underlying processes of adaptation and speciation. Freshwater snails offer many opportunities for such studies (e.g., DeJong et al. 2001, Mavárez et al. 2002, Facon et al. 2003, Albrecht et al. 2007, Strong et al. 2008), and among them the operculate family Ampullariidae seems particularly valuable in this regard.

The Ampullariidae have a primarily circumtropical distribution, reaching their highest diversity in South America. There are records of ampullariids from the Lower Cretaceous, $\sim 145$ million years before present (mybp), and the Upper Jurassic, 160 mybp, in Africa and Asia respectively (Wang 1984, Tracey et al. 1993, Van Damme and Pickford 1995), and their fossil record dates back at least 50 mybp in the Neotropics (Melchor et al. 2002). More than 150 nominal species are recognized in nine extant genera: Afropomus Pilsbry and

* From the symposium "Molluscs as models in evolutionary biology: from local speciation to global radiation" presented at the World Congress of Malacology, held from 15 to 20 July 2007 in Antwerp, Belgium. 
Bequaert, 1927, Saulea Gray, 1867, and Lanistes Montfort, 1810 are African; Pila Röding, 1798 is African and Asian; Asolene d'Orbigny, 1838, Felipponea Dall, 1919, Marisa Gray, 1824, and Pomella Gray, 1847 are South American; Pomacea Perry, 1810 ranges from Argentina to the southeastern U.S.A. and the Caribbean (Berthold 1991, Cowie and Thiengo 2003).

While the overall family-level morphology of ampullariids is relatively constrained, many species exhibit wide ontogenetic and ecophenotypic conchological variation, making identification and delimiting of species based on conchology alone very difficult. Internal anatomy offers some resolution (Thiengo 1989, Thiengo et al. 1993, 2007), but molecular analyses have begun to make it possible to identify welldemarcated lineages (species) (Cowie et al. 2006), and provide a phylogenetic framework to resolve fundamental taxonomic and systematic problems and address major evolutionary questions. Their long evolutionary history, wide geographic distribution, and high biodiversity make them especially well suited for studying biogeography, biodiversification, and novel adaptations to provide further insights into evolutionary biology in general.

This paper makes no attempt to review ampullariid evolution, phylogenetics, or systematics comprehensively. Rather, we summarize the basic knowledge of the evolution and biogeography of the group and discuss some of the opportunities mentioned above, especially in the light of our ongoing research on ampullariids, to illustrate their potential as vehicles for addressing questions in evolutionary biology.

\section{BIOGEOGRAPHY}

The family Ampullariidae is thought to have originated in the part of Gondwana that is now Africa. The origin of the family more than 150 mybp was followed by spread and diversification across Africa, Asia, and the Neotropics. Its absence in Australia is thought to be a result of the early separation of that continent $(>160$ mybp) prior to ampullariids reaching it (Berthold 1991). Studies of the wide distributions of the diverse species in Africa and the Neotropics should allow insights into both the higher level (generic) origins and patterns of diversification within the family. This will, in turn, provide additional insight into the biological, phylogenetic, and evolutionary consequences of the break up of Gondwana, by corroborating or contradicting patterns revealed by other groups of plants and animals. Insights gained from those ampullariid taxa with narrow distributions (Afropomus, Saulea, Felipponea, and perhaps Asolene) may also provide more detailed information about the precise geographic relationships and pathways of dispersal between particular sub-regions of the main parts of Gondwana, in particular certain parts of eastern South America and western Africa.
Clarification of the exact order and timing of ampullariid diversification and associated biogeographic patterns will not only provide a much better understanding of evolution within the group, but also contribute significantly to our knowledge of the mode and tempo of evolution, adaptive radiation, and distribution of other freshwater fauna. Also, because the distributions of ampullariids and speciation within the family are probably influenced by both vicariant events like the splitting of Gondwana and passive, long distance dispersal with flow in major river systems, studying ampullarids may help clarify the relative roles of each, an ongoing debate in biogeography (Cowie and Holland 2006, Holland and Cowie 2006, Nelson 2006).

\section{Global}

The global, historical biogeography of the Ampullariidae is not fully understood. Resolving remaining questions about the origins and diversification of the genera will require additional fossil and molecular data and a more complete phylogenetic analysis. However, published hypotheses, based until now only on anatomical and morphological data (Berthold 1991, Simone 2004), have provided an important starting point in answering these questions, and new molecular information is also refining our understanding. According to the morphological analyses (Berthold 1991, Bieler 1993), the Ampullariidae originated in Gondwana and, 140 million years ago, were restricted to parts of Gondwana as follows: Afropomus and Saulea in southern Africa, Lanistes in southern Africa and Madagascar, and the most recent common ancestor (MRCA) of Pila and the Recent Neotropical genera in southern Africa, Madagascar, southwestern India, and eastern South America (Fig. 1A). The subsequent break up of Gondwana led to diversification of this MRCA on the different land masses. It gave rise in South America to five genera: Pomella, Felipponea, Asolene, Marisa, and Pomacea with the first three diversifying early and Pomacea and Marisa being more derived (Berthold 1991, Bieler 1993). In Africa it gave rise to Pila, which spread also into Asia. Afropomus, Saulea, and Lanistes remained on the African continent and, in the case of Lanistes, in Madagascar (Fig. 1A). However, recent studies using DNA sequence data challenge this scenario (Schultheiß et al. 2007, Jørgensen et al. 2008). In contrast to Berthold's (1991) phylogeny, Pila and Lanistes appear as sister taxa in most molecular analyses, suggesting a different Gondwanan distribution of the Ampullariidae from that Berthold had suggested. According to the molecular scenario, the ampullariid ancestor gave rise to two lineages: that giving rise to modern Afropomus and that giving rise to all other extant ampullariids. This second lineage then split into two lineages. One of these gave rise to the sister taxa Lanistes and Pila and diversified within Africa, colonizing Madagascar and, in the case of Pila, Asia; the other, the MRCA of Saulea and the New World taxa, colonized South America 

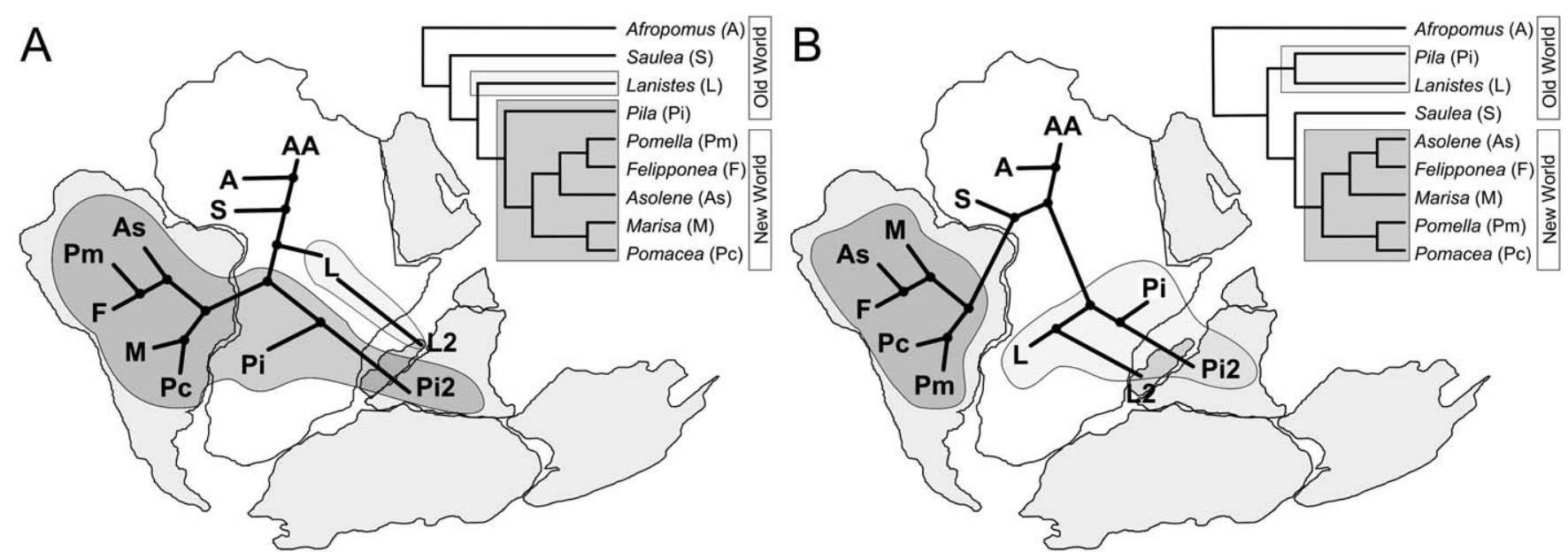

Figure 1. Two hypotheses of Ampullariidae biogeography and diversification. A, the morphological based hypothesis of Berthold (1991) assumes an ampullariid ancestor (AA) giving rise to Afropomus, Saulea, and Lanistes in southern Africa, with Lanistes spreading to Madagascar, and the MRCA of Pila and recent Neotropical genera splitting in Africa with Pila diversifying in southern Africa, Madagascar and Asia, and the five Neotropical genera diversifying throughout South and Central America. B, the DNA based scenario (Hayes 2007, Schultheiß et al. 2007, Jørgensen et al. 2008) showing the initial divergence of two main lineages in Africa, one giving rise to Afropomus and the other diversifying again and giving rise to Pila and Lanistes, which diversified within Africa but also colonized Madagascar with Pila spreading to Asia. The final lineage, probably sharing a MRCA with Saulea, colonized South America, diversifying into the five currently recognized New World genera. Shading highlights represent the major differences between the two hypotheses. Late Jurassic Gondwana maps (ca. 150 mybp) are redrawn from Scotese (2002).

and gave rise to the modern Saulea in Africa and the five New World genera (Fig. 1B). However, ongoing research (Hayes et al. 2009) shows that this relationship is sensitive to the inclusion of Cyclophoridae as an outgroup (cf. McArthur and Harasewych 2003), which results in Saulea being basal in a monophyletic African clade (Saulea, Pila, Lanistes, Afropomus).

\section{Old World}

Of the four African ampullariid genera, Lanistes, Pila, Afropomus, and Saulea, the latter two are monotypic and restricted to Liberia, Sierra Leone, and the Ivory Coast (Brown 1994). This area is known for its high proportion of endemic freshwater fauna and is considered a distinct freshwater bioregion, Upper Guinea (Thieme et al. 2005). The ampullariid fauna in this small region has been considered old and relictual (Van Damme 1984), and given the region's close geological ties with northeastern South America, makes it a likely candidate for the location of the sister taxa of the New World ampullariids. This contrasts somewhat with Berthold's (1991) scenario in which he placed the original distribution of ampullariids in South America along the southern coast of what is now Brazil. Pila and Lanistes are generally more widespread in Africa though both genera have widespread as well as locally restricted species. Fossils of both genera are known from the late Cenozoic of the Albertine Rift Valley (Van Damme and Pickford 1995).
The five African species of Pila currently recognized (Brown 1994) are distributed across Africa with no clearly discernable biogeographic pattern. Pila ovata (Olivier, 1804) is the only widespread species, although with four of its historically named forms being relatively distinct (MandahlBarth 1954). Lanistes is more speciose than African Pila with 19 currently recognized species, mostly with very limited (known) distributions (Brown 1994). Lanistes occurs both in Madagascar and Africa from the lower Nile south to KwaZuluNatal and the Okavango Delta (Brown 1994). Presuming an age of Lanistes of tens of millions of years, and with the difficulty of delimiting species morphologically, intensive geographical sampling and molecular analysis, as in other ampullariid groups, will probably reveal additional cryptic species. For instance, Lanistes ovum Peters, 1845 is the only widespread species of Lanistes, and although many nominal taxa have been reduced to synonymy with it, some at least may represent cryptic species, with $L$. ovum in fact being a species complex rather than a single species. Molecular analyses of this widely distributed African taxon will be necessary to resolve this issue. The biogeography of Lanistes especially is a field wide open for investigation.

In Asia, Pila is the only native genus. Prashad (1925) recognized ten species of Pila in India, including two species of Turbinicola Annandale and Prashad, 1921, which is a junior synonym (Berthold 1991). Otherwise, Asian Pila, of which 
there may be about 25 species based on Berthold's (1991) estimate of about 30 species in the genus as a whole, have not been revised comprehensively and their distributions, systematics, and biogeography are therefore also ripe for study.

\section{Neotropics}

In general, Neotropical freshwater biogeography may be better understood than that of Africa, especially with regard to ampullariids. Tectonic events and climatic fluctuations have probably influenced the diversity and distribution of New World ampullariids. The emergence of the Antillean archipelago ( 49 mybp; Graham 2003) may have facilitated diversification by both vicariance and dispersal. Connection of the West Indies to northwestern South America, ending 32 mybp (Iturralde-Vinent and MacPhee 1999), may have been important. Other 'land-based' scenarios are also possible. There are two main groups of hypotheses to explain Neotropical freshwater biodiversity. Refuge hypotheses (Haffer 1982) posit that diversification resulted primarily from multiple habitat fragmentation and coalescence events driven primarily by Pleistocene climate changes (1.8 million - 11,000 ybp). Hydrogeological hypotheses (Lundberg 1998) suggest that current diversity was reached much earlier, resulting from the changing relationships among South American river systems and their drainages 90-10 mybp. Hydrogeological changes related to tectonic events drove diversification by fracturing and reuniting aquatic habitats multiple times, leading to allopatric speciation. These hypotheses place divergences among drainage biotas much earlier than refuge hypotheses and offer multiple time points that may be correlated to cladogenic events (Sivasundar et al. 2001, Montoya-Burgos 2003). Finally, the rise and completion of the Isthmus of Panama $\sim 3$ mybp (Coates and Obando 1996) provided nonmarine connections between South and Central American drainages. Phylogeographic patterns in several freshwater fish genera suggest multiple waves of dispersal through Central America from South America (Bermingham and Martin 1998, Perdices et al. 2002).

A combination of hypotheses may thus explain New World ampullariid diversification. But historical biogeographic inferences rely on the fossil record and knowledge of phylogenetic relationships of extant taxa; in both regards New World ampullariids are poorly known. Limited fossil evidence places Pomacea in South America 50 mybp but an earlier, possibly Gondwanan, origin has been suggested (Berthold 1991, Melchor et al. 2002), with origin and diversification of contemporary New World taxa occurring in South America soon after breakup of the supercontinent ( 180 mybp). An ancient origin of South American ampullariids supports the hydrogeological hypothesis but remains conjecture without knowledge of the temporal pattern of diversification. Thus, New World ampullariids have the potential to illuminate and discriminate among these various general hypotheses of the diversification of the freshwater biota.

In South and Central America, based on molecular analysis (Fig. 1B), the lineage that probably gave rise to the genus Saulea in Africa diversified into five currently recognized genera, Pomella, Asolene, Marisa, Felipponea, and Pomacea. Reconstruction of the relationships within the family, based on morphology, placed Asolene as the most basal of the New World ampullariids with close ties to both Felipponea and Pomella (Berthold 1991, Bieler 1993). Pomacea and Marisa were placed in more derived positions and as sister taxa (Fig. 1A). Pomella has a rather disjunct distribution, with Pomella americanista (Ihering, 1919) and Pomella megastoma (Sowerby, 1825) (subgenus Pomella sensu stricto) occurring in the south (Argentina, Uruguay, Paraguay, southern Brazil) and Pomella sinamarina (Bruguière, 1792) (subgenus Surinamia) in the north of the continent (Guyana, Suriname, French Guiana). Similarly, the distribution of Asolene is non-contiguous, with some species occurring in the south and others restricted to the north. The three species recognized by Cowie and Thiengo (2003) in Felipponea are restricted to the south (Argentina, Uruguay, Paraguay, southern Brazil). Taxa in the more derived Marisa-Pomacea clade have much wider and somewhat more contiguous distributions. The two species of Marisa are distributed from southern Brazil through northern South America and Trinidad and Tobago. Marisa planogyra Pilsbry, 1933 occurs primarily in the south and Marisa cornuarietis (Linnaeus, 1758) in the north, with some possible overlap in northern Brazil. Pomacea is the largest and most diverse genus and has the widest distribution, occurring from Argentina through Central America, the Caribbean and into southeastern North America.

Multi-gene phylogenetic results from recent work on New World ampullariids are largely in agreement with previous hypotheses, placing Pomacea as the most derived group of New World ampullariids (Hayes 2007, Hayes et al. 2009). However, Pomacea as currently recognized (Cowie and Thiengo 2003) is not monophyletic, as also suggested by Simone (2004) in his morphological study. Similarly, Hayes (2007) found no support for monophyletic Asolene, Felipponea, or Marisa. Instead, both species of Marisa, two species of Felipponea, and several species of Asolene were recovered in a single well-supported basal clade, sister to a clade consisting of other species of Asolene and Pomacea (Fig. 2). These two clades were in turn sister to the larger well-supported group containing the remaining Pomacea species and the only Pomella species included in the analysis, Pomella megastoma. In the past, assignment of species to these genera, especially to Asolene, Felipponea, and Pomella, based on morphological criteria, has been inconsistent (Cowie and Thiengo 2003); these molecular results will help to circumscribe these poorly understood genera. Also, these preliminary data begin to clarify 


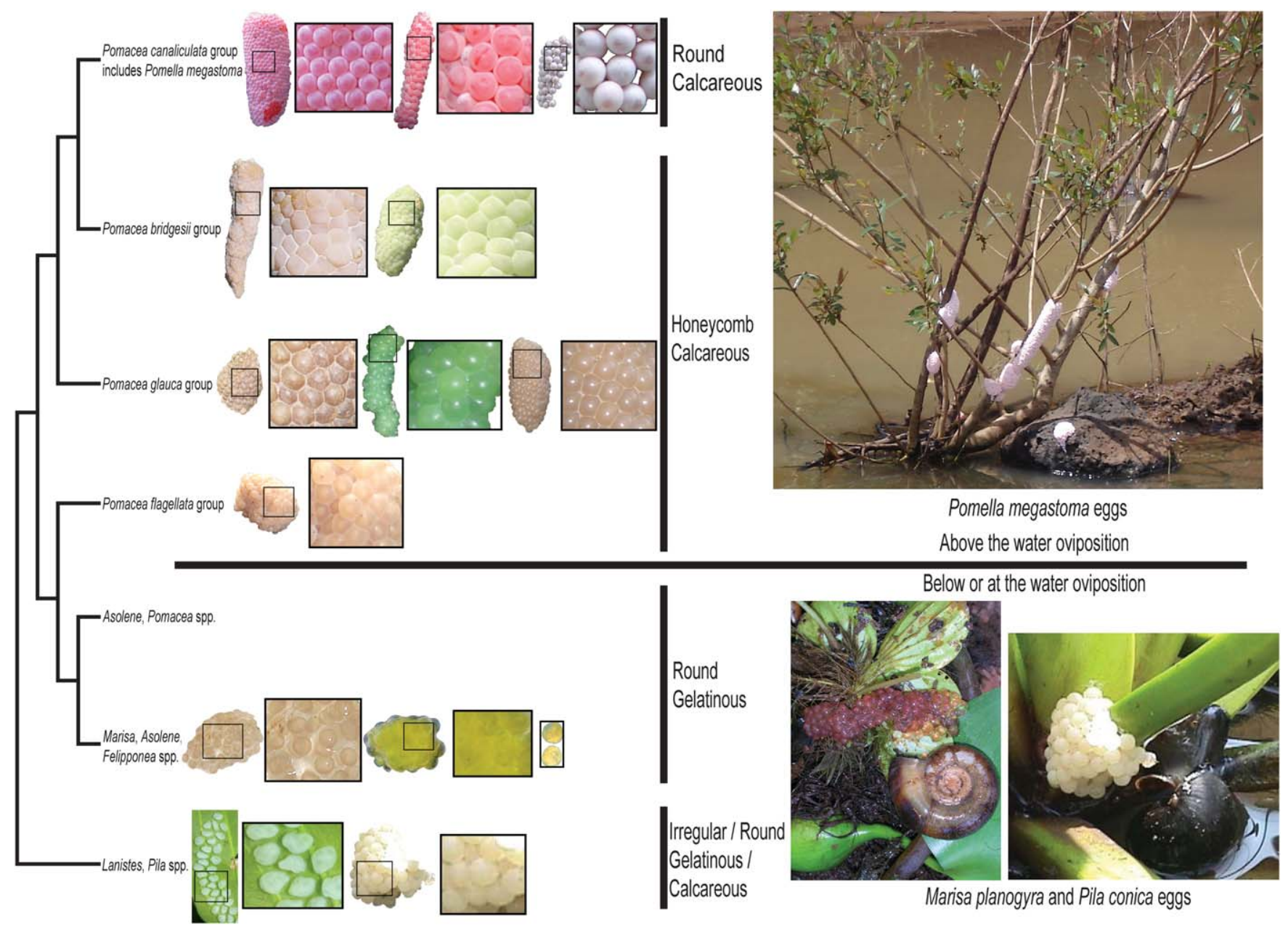

Figure 2. Ampullariidae phylogeny based on analysis of one mitochondrial and three nuclear genes showing the relationships among the major clades of the monophyletic New World genera (Hayes 2007). Egg morphology and oviposition location are mapped onto the major groups illustrating the evolutionary shift from laying gelatinous eggs below the water to laying calcareous eggs on emergent vegetation. Representative egg clutches from species within each of the major lineages illustrate a high level of morphological conservation within groups. From left to right egg clutches are: Top row, Pomacea insularum (d'Orbigny, 1835), Pomacea canaliculata, Pomacea paludosa; second row, Pomacea diffusa Blume, 1957, Pomacea bridgesii (Reeve, 1856); third row, Pomacea sp., Pomacea glauca, Pomacea guyanensis (Lamarck, 1822); fourth row, Pomacea catemacensis (Baker, 1922); fifth row, Asolene spixii (d'Orbigny, 1838), Felipponea sp.; bottom row, Lanistes ovum, Pila conica (Wood, 1828). Photo credits: J. F. R. Amato (Felipponea sp.), K. C. M. Heiler (Lanistes ovum), J.-P. Pointier (Pomacea glauca), R. C. Joshi (Pila conica), K. Gallagher (Asolene spixii), S. C. Thiengo (Marisa planogyra), and K. A. Hayes (all others).

the biogeographic patterns of diversification in New World ampullariids and reveal insights into factors like desiccation resistance, oviposition, and predation pressure that may have played a role in this diversification (Hayes 2009). These issues are discussed below.

\section{BIODIVERSITY AND SPECIATION}

The family Ampullariidae contains more than 150 species, and reaches its highest diversity in the Neotropics with the genus Pomacea, which contains 117 nominally valid species (Cowie and Thiengo 2003). The question of why there are so many Neotropical species has intrigued scientists since Alfred Russel Wallace (1852) first proposed that rivers act as barriers, driving allopatric speciation in Amazonian monkeys. Since then several explanations have been proposed, including Haffer's (1969) explanation of bird diversity in the context of the so-called "refuge hypothesis" and explanations of freshwater ichthyofaunal diversity based on the "hydrogeological hypothesis" (Lundberg et al. 1998, Montoya-Burgos 2003). Most explanations of high levels of Neotropical diversity have 
been based on vertebrates, invoking vicariance as the primary isolating mechanism (Hall and Harvey 2002, Costa 2003, Ribas et al. 2005).

Conspicuously lacking are studies of the huge diversity of invertebrates, including Neotropical freshwater molluscs and studies looking specifically at the complex inter- and intraspecific interactions that drive speciation. Ampullariids have the potential to provide insight into these issues, as well as to reveal other less studied mechanisms generating diversity (Vermeij and Covich 1978, Endler 1982).

Since Darwin (1859), evolutionary biologists have suggested that ecology plays a vital part in the origin of species (Schluter 2001, Via 2002). The evolutionary ecology of apple snails has great potential for shedding light on the various processes involved in population divergence and ultimately speciation. Here, we address three of these, which may overlap; there are probably others equally amenable to investigation using these snails. First, the interaction between apple snails and their predators, their trophic relations, may influence natural selection regimes acting on both predator and prey. Studies focusing on these interactions should provide key insights into the evolution of these relationships and predator prey co-evolution in general, which in turn will provide information about how such processes help shape biodiversity. Second, habitat partitioning among ampullariids within an ecosystem may provide the necessary isolation for divergent selection to reinforce adaptations leading to reproductive isolation. These interactions may represent major drivers of evolutionary change. Third, because of their wide latitudinal distribution and high species level diversity, ampullariids offer an exciting opportunity to investigate large-scale patterns, or rules, of biodiversity, including Rapoport's Rule and the latitudinal diversity gradient.

\section{Trophic relations}

Throughout their range, ampullariids are major constituents of tropical/subtropical freshwater diversity and are key taxa in important aquatic ecosystems such as the Florida Everglades, the Llanos of Venezuela, and the Pantanal of central South America (Donnay and Beissinger 1993, Fellerhoff 2002, Brown et al. 2006). They may even serve as important indicators of ecosystem health (Ogden et al. 2005). In these systems, they are the main food of snail kites, which include the endangered Everglades Snail Kite, Rostrhamus sociabilis plumbeus, and closely related congeners (i.e., Rostrhamus hamatus). Because of the abundance of apple snails in these ecosystems and their role in the diet of a variety of animals (birds, fishes, turtles, crocodilians), they could be considered keystone prey species and an important link between aquatic and terrestrial food chains (Donnay and Beissinger 1993, Ebenman and Jonsson 2005). Studies of trophic relationships indicate that these links may have a large influence on species diversity (Paine 1966, Kondoh 2003).

Populations of species coupled in predator-prey relationships may often be ecologically linked through both conspicuous predator-prey interactions (Connell 1961, Vermeij 1982) and more cryptic evolutionary dynamics (Yoshida et al. 2007). For instance, variation in the distribution and abundance of apple snail species has been shown to influence the distribution (Angehr 1999), abundance (Darby et al. 2006), and behavior (Tanaka et al. 2006) of snail kites, which have evolved both morphologically and behaviorally for extreme specialization on apple snails (Beissinger et al. 1994). At the same time, predation pressure, by kites and other predators, has probably shaped the morphological and behavioral adaptations of apple snails. For example, Reed and Janzen (1999) determined that the foraging behavior of limpkins (Aramus guarauna) resulted in disruptive selection on shell size in Pomacea flagellata (Say, 1829) in Costa Rica. They also observed directional selection against larger, light-colored snails by snail kites. Dieckmann and Doebeli (1999) modeled just such a predator-prey system and found that predator-prey interactions, when coupled with demographic stochasticity and the resulting genetic drift and assortative mating, often leads to evolutionary branching, which could result in sympatric speciation. Providing further evidence of possibly important evolutionary interactions, Snyder and Snyder (1971) found that Pomacea paludosa (Say, 1829), Pomacea glauca (Linnaeus, 1758), and Pomacea dolioides (Reeve, 1856) exhibit alarm responses to chemical cues from turtle predators, injured or dead conspecifics, and mechanical disturbance.

Similar processes may also have shaped the diversity of Old World ampullariids. Van Damme and Pickford (1995) suggested that rapid radiations of Lanistes spp. and changes in Pila spp. in the Rift Valley lakes of East Africa were probably the result of selection pressure from specialized predators, particularly fishes. Rapid and successive morphological changes in these two genera were inferred to have occurred ca. 8-2.5 mybp. A series of impressive Lanistes radiations involving rapid, major changes in shell morphology provides a good model for understanding speciation processes (Van Damme and Pickford 1995). Specifically, two successive radiations occurred, first in Paleolake Obweruka and later in Lake Malawi, both demonstrating convergence on antipredatory behaviors and morphologies characteristic of a number of Rift Valley lake mollusc species. Some of the patterns seen, particularly thalassoidism (i.e., shell form resembling marine gastropod species), were attributed to predator-prey interactions that may have triggered speciation. The repetitive ampullariid radiations were considered as conforming to a punctuated equilibrium model of evolutionary change (Van Damme and Pickford 1995) although such interpretations of African Great Lake fossil gastropod faunas 
have long been criticized (e.g., Jones 1981). The fossil radiations may be useful in understanding patterns of more recent radiations of African ampullariids, especially if change in shell morphology can be linked to genetic change.

Almost all theory on the tempo and mode of speciation in Lake Malawi, while providing major insight into evolutionary processes, rests on the study of cichlid fishes (Kocher 2004). The recent ampullariid radiation in Lake Malawi was studied morphologically by Berthold (1990), but a detailed molecular study of these snails would potentially shed further light on these questions using a non-fish model system. Recent studies of the Lake Malawi radiation (Jørgensen et al. 2008, Schultheiß, Van Bocxlaer, Albrecht, and Wilke, pers. comm.) revealed relatively low genetic variation within this clade. This might indicate a young evolutionary age of the radiation, a suggestion previously made by Berthold (1990). In combination with modern morphometric analyses, molecular methods will help to identify general patterns of diversification in ancient lakes, which will help clarify any differences in mode and tempo of speciation between vertebrate taxa like cichlid fish and invertebrates like the ampullariid genus Lanistes.

\section{Habitat partitioning}

In addition to predator-prey interactions, other aspects of ampullariid ecology have probably influenced their current diversity. African Lanistes have both lacustrine (e.g., Lake Malawi, see above) and riverine (e.g., Congo River basin) radiations. In Lake Malawi Lanistes nyassanus Dohrn, 1865 and Lanistes solidus Smith, 1877 differ in their use of microhabitats along a depth gradient, probably related to food availability and differential response to cichlid predators (Louda et al. 1984). Further, using the Lanistes spp. of Lake Malawi as an example, Berthold (1991) explored aspects of speciation and evolution of shell sculpture within the framework of a multidimensional niche concept. He proposed that speciation of Lake Malawi Lanistes was driven by differential adaptations to wave action, food resources, and predators (particularly habitat and behavioral shifts for predator avoidance). Such a scenario has the classic elements that would be anticipated in a case of ecological speciation, whereby reproductive isolation builds between two populations that accumulate adaptations to unique aspects of their environment (Schluter 2001).

The Congo River basin radiation of Lanistes consists of Lanistes bicarinatus Germain, 1907, Lanistes congicus Boettger, 1891, Lanistes intortus Martens, 1877, and Lanistes nsendweensis (Dupuis and Putzeys, 1901). The high levels of conchological variation among these species makes inferring their monophyly difficult based on morphological analysis. Nonetheless, this great variation suggests a role of ecology in species diversification. Investigation of this radiation should focus initially on ascertaining its age, documenting genetic variation, determining monophyly, and identifying common ancestors. However, while it is an example of neither true riverine nor true lacustrine speciation, it offers the possibility of investigating speciation in a habitat type (river basin) that is more permanent on both ecological and evolutionary timescales than most lake habitats (Giller and Malmquist 1998). If future molecular investigations reject the monophyly of the Congo species, then the basin might be interpreted as a refuge that has been stable over the long term rather than a place of species radiation.

\section{Large-scale biodiversity rules}

A number of patterns of species diversity have been documented across a wide range of taxonomic groups. Most notably, these patterns include Rapoport's Rule - a positive correlation between species ranges and latitude (Stevens 1989), Bergmann's rule - increasing body size with increasing latitude in mammals and birds (Bergmann 1847), and the latitudinal biodiversity gradient - decreasing species richness from tropical to polar latitudes (Dobzhansky 1950). The latitudinal biodiversity gradient is one of the longest recognized and most universally accepted patterns in nature (Darwin 1859, Wallace 1878, Hutchinson 1959, Wright et al. 2006), yet there remains little agreement regarding the underlying mechanisms responsible for it (Mittelbach et al. 2007).

Three broad categories of explanations have been proposed to explain the gradient, involving ecological, evolutionary, and historical hypotheses (Mittelbach et al. 2007). Ecological hypotheses focus on processes of species coexistence and the maintenance of species diversity through species interactions, and apple snails have been mentioned above as a system with which to investigate such processes. Evolutionary hypotheses focus on rates of diversification. And historical explanations are based on the persistence and extent of tropical environments. Understanding the relationship between latitude and speciation has been hindered by a lack of comparative analyses across a single clade that inhabits both tropical and temperate regions. Here again, apple snails may serve as a good system for investigating the underlying processes, and they can be used to test explicitly several of the proposed hypotheses.

The oft-cited "diversification rate hypothesis" suggests that high tropical diversity results from high rates of speciation (Fischer 1960) caused by one or more of the following: (1) greater opportunities for reproductive isolation because lower latitudes contain larger area (Terborgh 1973), (2) increased rates of molecular evolution due to higher metabolic rates in warmer regions (Rohde 1992, Wright et al. 2006), (3) enhanced biotic interactions because of increased specialization and reduced dispersal (Dobzhansky 1950, Janzen 1967), and (4) lower extinction rates due to increased climatic stability (Darwin 1859, Fischer 1960) or larger population sizes (Terborgh 1973). 
Using ampullariids to investigate the various mechanisms responsible for higher levels of tropical than of temperate diversity will require data from paleontology, biogeography, ecology, and phylogenetics. However, using preliminary data (Hayes 2009) we can begin addressing at least one of these hypotheses. The explanation of Rohde (1992), supported by Wright et al. (2006), posits that higher tropical diversity results from an increased rate of molecular evolution in the tropics relative to higher latitudes. Species of Pomacea are an ideal group to test this hypothesis, as they range from temperate Argentina to the southeastern U.S.A. Using the approach of Wright et al. (2006), rate heterogeneity in molecular evolution can be tested using sister taxa, one of which occurs in the tropics and the other in a temperate region (e.g., Pomacea canaliculata (Lamarck, 1822) and Pomacea dolioides). Hayes (2009) found that ampullariid diversity indeed decreases with increasing latitude. If future research finds a difference in rate of evolution, these taxa could be used to investigate further the possible mechanisms driving the differences.

The "historical time and area hypothesis" contends that areas with tropical climates are historically larger and older, which has allowed more opportunity for diversification (Fischer 1960, Wiens et al. 2006). If this were the primary driver of greater tropical versus temperate diversity, we should expect tropical species to be older and temperate species to be nested within clades of tropical taxa. Also we should expect diversity to be correlated with the age of geographical regions. Data emerging from ongoing work on ampullariids (Schultheiß et al. 2007, Jørgensen et al. 2008, Hayes et al. 2009) are beginning to provide the phylogenetic and biogeographic framework to address such hypotheses.

\section{PHYSIOLOGY AND BEHAVIOR}

In addition to addressing broad questions of biogeography and speciation, apple snails provide an excellent system for studying the evolution of physiological and behavioral adaptations, aspects of which may have profound implications for the generation of diversity, and for addressing important questions in behavioral ecology and evolution. Mapping apple snail oviposition location onto a preliminary phylogeny, Hayes (2007) found that laying eggs on emergent vegetation or other above-water hard surfaces is a synapomorphy that unites the most derived clade consisting predominantly of snails currently referred to Pomacea. Other ampullariids, including Old World and basal New World taxa, oviposit either on vegetation below or at the water line or in mud close to it (Cowie 2002) (Fig. 2). This observation, combined with the fact that this derived group is also the most speciose and covers the widest geographical range, leads to speculation that this shift to above water oviposition may have been a key innovation that accompanied the diversification and spread of the group. Other characteristics in the above-water egglaying group seem to include longer siphons (for aerial respiration), increased lung size, and increased desiccation resistance (Cowie 2002). All these factors may be correlated with the success of the group.

Unique egg morphologies are associated with each of the clades in this above-water oviposition group, with the most derived group having spherical eggs that cluster relatively loosely in the egg mass. The more basal taxa in this group lay eggs that are honeycombed or polygonal in shape and abut tightly against one another within the egg mass (Fig. 2). It is possible that the derived condition of spherical, loosely clustered eggs may also have contributed to the success of these taxa through increased hatching rate resulting from more efficient respiration through the egg shell although respiration rates in clutches with different morphologies have yet to be measured.

Nuptial feeding is any form of nutrient transfer from the male to female during or directly after courtship or copulation. Burela and Martín (2007) reported nuptial feeding in Pomacea canaliculata, the first time it has been reported in a gastropod. Such behavior has implications for sexual selection and fitness. Burela and Martín (2007) discussed several possible advantages, including enhanced male fitness through benefits conferred to the offspring via additional nutrients, and mate attraction, mate acceptance, or increasing the length of copulation to maximize sperm transfer. Either way, this is a fascinating behavior that has interesting evolutionary implications for apple snails and mating behavior in general. Burela and Martín (2007) suggested that given the high level of similarity in the general body plan across the Ampullariidae, this behavior is probably not exclusive to this species, and may be found more widely.

\section{BIOLOGICAL INVASIONS}

Invasive species are now recognized throughout the world as a major economic and environmental threat (Pimentel et al. 2005, Puth and Post 2005). While these alien invasions cause tremendous agricultural, conservation, and human health problems, the rapid evolutionary changes that often accompany such unplanned invasion experiments may permit a greater understanding of the natural world, and at the same time provide insights into a variety of ecological and evolutionary processes (Sax et al. 2007). That rapid evolutionary changes occur after the introduction of alien species has become increasingly well documented (Cox 2004, Carroll et al. 2005, Huey et al. 2005), and more studies are taking advantage of these "accidental experiments" to investigate contemporary evolution. Such changes may often 
take place in tens to hundreds of generations instead of the millions that most evolutionary processes are normally thought to occur over, and they take place in both the alien and the native species that interact during invasions (Sax et al. 2007). A number of ampullariid species have become invasive outside their native ranges, particularly species of Pomacea and Marisa (Joshi and Sebastian 2006, Rawlings et al. 2007, Hayes et al. 2008). It is possible that the adaptive genetic changes necessary to be successful invasives are occurring rapidly in these species, and these processes may be understood better by integrating ecological and evolutionary perspectives. Wada and Matsukura (2007) have shown that Pomacea canaliculata has adopted at least two strategies for dealing with overwintering in its introduced range in Japan: burial in mud or seeking refuge under rice straw before the onset of winter. They found seasonal differences in cold hardiness of snails, suggesting that cold winters may impose strong natural selection on such populations. It is still uncertain whether this is an adaptation acquired after introduction or one possessed by source populations in their native ranges. However, in either case it demonstrates that ampullariids may be an illuminating system for studying adaptive strategies of introduced species. Because multiple ampullariid species have been introduced, comparative studies among them may reveal key differences in such strategies. The results of such studies will not only strengthen our understanding of invasion biology but may also allow us to investigate the patterns and tempo of adaptive genetic changes along with the influence of founder events on these processes.

\section{CONCLUSIONS}

More than 150 years after Darwin's revolutionary idea of descent with modification, there remain a number of unanswered questions fundamental to our understanding of evolution and biodiversity. How many species are there? How are these species distributed? What are the processes that generate this biodiversity? Many of these questions remain unanswered simply because of the complexity of the evolutionary process. For example, the myriad mechanisms that might lead to the evolution of reproductive isolation (i.e., speciation) are often difficult to disentangle. Yet addressing these issues in a range of groups, particularly those with the highest diversity, may reveal additional insights that will go a long way to answering these big evolutionary questions. Ampullariids offer an excellent system for addressing many of these questions, particularly regarding the generation of biodiversity and how it spread and diversified around the globe. Lessons learned from this group may be generalized not only to other freshwater taxa but also to more profound and over-arching themes in evolutionary biology.

\section{ACKNOWLEDGMENTS}

We thank Matthias Glaubrecht and Thomas von Rintelen for inviting us to participate in the symposium they organized and for the invitation to write this contribution. We owe a debt of gratitude to numerous collaborators for their help obtaining ampullariid material from around the world, particularly those in SE Asia and Brazil. Funding was provided to RHC by the U.S. Department of Agriculture and to KAH by the Ecology, Evolution, and Conservation Biology program of the University of Hawaii (NSF grants DGE0232016 and DGE0538550 to K. Y. Kaneshiro) and an American Malacological Society Student Research Award. KAH's attendance at the symposium was partially funded by a grant from Unitas Malacologica. The Villum Kann Rasmussen Foundation provided funding to $\mathrm{AJ}$ in support of his research and attendance at the symposium.

\section{LITERATURE CITED}

Albrecht, C., K. Kuhn, and B. Streit. 2007. A molecular phylogeny of Planorboidea (Gastropoda, Pulmonata): Insights from enhanced taxon sampling. Zoologica Scripta 36: 27-39.

Angehr, G. R. 1999. Rapid long-distance colonization of Lake Gatun, Panama by snail kites. Wilson Bulletin 111: 265-268.

Beissinger, S. R., T. J. Donnay, and R. Walton. 1994. Experimental analysis of diet specialization in the snail kite: The role of behavioral conservatism. Oecologia 100: 540-565.

Bergmann, C. 1847. Über die Verhältnisse der Wärmeökonomie der Thiere zu ihrer Grösse. Göttinger Studien, Göttingen 3: 595-708 [In German].

Bermingham, E. and A. P. Martin. 1998. Comparative mtDNA phylogeography of neotropical freshwater fishes: Testing shared history to infer the evolutionary landscape of lower Central America. Molecular Ecology 7: 499-517.

Berthold, T. 1990. Intralacustrine speciation and the evolution of shell sculpture in gastropods of ancient lakes - application of Günther's niche concept. Abhandlungen des Naturwissenschaftlichen Vereins in Hamburg (NF) 31/32: 85-118.

Berthold, T. 1991. Vergleichende Anatomie, Phylogenie und Historische Biogeographie der Ampullariidae (Mollusca, Gastropoda). Abhandlungen des Naturwissenschaftlichen Vereins in Hamburg (NF) 29: 1-256 [In German].

Bieler, R. 1993. Ampullariid phylogeny-Book review and cladistic re-analysis. The Veliger 36: 291-299.

Brown, D. S. 1994. Freshwater Snails of Africa and Their Medical Importance, $2^{\text {nd }}$ Edition. Taylor \& Francis, London.

Brown, M. T., M. J. Cohen, E. Bardi, and W. W. Ingwersen. 2006. Species diversity in the Florida Everglades, USA: A systems approach to calculating biodiversity. Aquatic Sciences 68: 254277.

Burela, S. and P. B. Martín. 2007. Nuptial feeding in the freshwater snail Pomacea canaliculata (Gastropoda: Ampullariidae). Malacologia 49: 465-470. 
Carroll, S. P., J. E. Loye, H. Dingle, M. Mathieson, T. R. Famula, and M. P. Zalucki. 2005. And the beak shall inherit-evolution in response to invasion. Ecology Letters 8: 944-951.

Coates, A. G. and J. A. Obando. 1996. The geologic evolution of the Central American isthmus. In: J. Jackson, A. F. Budd, and A. G. Coates, eds., Environment and Evolution in Tropical America. Chicago University Press, Chicago. Pp. 21-56.

Connell, J. H. 1961. The influence of interspecific competition and other factors on the distribution of the barnacle Chthamalus stellatus. Ecology 42: 710-723.

Costa, L. P. 2003. The historical bridge between the Amazon and the Atlantic forest of Brazil: A study of molecular phylogeography with small mammals. Journal of Biogeography 30: 71-86.

Cowie, R. H. 2002. Apple snails (Ampullariidae) as agricultural pests: Their biology, impacts and management. In: G. M. Barker, ed., Molluscs as Crop Pests. CABI Publishing, Wallingford, U.K. Pp. 145-192.

Cowie, R. H. and S. C. Thiengo. 2003. The apple snails of the Americas (Mollusca: Gastropoda: Ampullariidae: Asolene, Felipponea, Marisa, Pomacea, Pomella): A nomenclatural and type catalog. Malacologia 45: 41-100.

Cowie, R. H. and B. S. Holland. 2006. Dispersal is fundamental to biogeography and the evolution of biodiversity on oceanic islands. Journal of Biogeography 33: 193-198.

Cowie, R. H., K. A. Hayes, and S. C. Thiengo. 2006. What are apple snails? Confused taxonomy and some preliminary resolution. In: R. C. Joshi and L. C. Sebastian, eds., Global Advances in Ecology and Management of Golden Apple Snails. Philippine Rice Research Institute, Muñoz, Nueva Ecija, Philippine. Pp. 3-23.

Cox, G. W. 2004. Alien Species and Evolution: The Evolutionary Ecology of Exotic Plants, Animals, Microbes, and Interacting Native Species. Island Press, Washington, D.C.

Darby, P. C., R. E. Bennetts, and L. B. Karunaratne. 2006. Apple snail densities in habitats used by foraging snail kites. Florida Field Naturalist 34: 37-68.

Darwin, C. 1859. On the Origin of Species by Means of Natural Selection. John Murray, London.

DeJong, R. J., J. A. T. Morgan, W. Lobato Paraense, J. P. Pointier, M. Amarista, P. F. K. Ayeh-Kumi, A. Babiker, C. S. Barbosa, P. Brémond, A. P. Canese, C. Pereira de Souza, C. Dominguez, S. File, A. Gutierrez, R. N. Incani, T. Kawano, F. Kazibwe, J. Kpikpi, N. J. S. Lwambo, R. Mimpfoundi, F. Njiokou, J. N. Poda, M. Sene, L. E. Velásquez, M. Yong, C. M. Adema, B. V. Hofkin, G. M. Mkoji, and E. S. Loker. 2001. Evolutionary relationships and biogeography of Biomphalaria (Gastropoda: Planorbidae) with implications regarding its role as host of the human bloodfluke, Schistosoma mansoni. Molecular Biology and Evolution 18: 2225-2239.

Dieckmann, U. and M. Doebeli. 1999. On the origin of species by sympatric speciation. Nature 400: 354-357.

Dobzhansky, T. 1950. Evolution in the tropics. American Scientist 38: 208-221.

Donnay, T. J. and S. R. Beissinger. 1993. Apple snail (Pomacea doliodes $[s i c]$ ) and freshwater crab (Dilocarcinus dentatus) population fluctuations in the Llanos of Venezuela. Biotropica 25: 206-214.
Ebenman, B. and T. Jonsson. 2005. Using community viability analysis to identify fragile systems and keystone species. Trends in Ecology and Evolution 20: 568-575.

Endler, J. 1982. Convergent and divergent effects of natural selection on color patterns in two fish faunas. Evolution 36: 178-188.

Facon, B., J.-P. Pointier, M. Glaubrecht, C. Poux, P. Jarne, and P. David. 2003. A molecular phylogeography approach to biological invasions of the New World by parthenogenetic thiarid snails. Molecular Ecology 12: 3027-3039.

Fellerhoff, C. 2002. Feeding and growth of apple snail Pomacea lineata in the Pantanal wetland, Brazil-a stable isotope approach. Isotopes in Environmental Health Studies 38: 227-243.

Fischer, A. G. 1960. Latitudinal variations in organic diversity. Evolution 14: 64-81.

Giller P. S. and B. Malmqvist. 1998. The Biology of Streams and Rivers. Oxford University Press, Oxford.

Graham, A. 2003. Historical phytogeography of the Greater Antilles. Brittonia 55: 357-383.

Haffer, J. 1969. Speciation in Amazonian forest birds. Science 165: 131-137.

Haffer, J. 1982. General aspects of the refuge theory. In: G. T. Prance, ed., Biological Diversification of the Tropics. Columbia University Press, New York. Pp. 6-24.

Hall, J. P. and D. J. Harvey. 2002. The phylogeography of Amazonia revisited: New evidence from Riodinid butterflies. Evolution 56: 1489-1497.

Hayes, K. A. 2007. Molecular systematics and evolutionary patterns of diversification in New World Ampullariidae. In: K. Jordaens, N. Van Houtte, J. Van Goethem, and T. Backeljau, eds., Abstracts of the World Congress of Malacology 2007, Antwerp, Belgium. Unitas Malacologica, Antwerp. P. 93.

Hayes, K. A. 2009. Evolution, molecular systematics and invasion biology of Ampullariidae. Ph.D. Dissertation, Department of Zoology, University of Hawaii, Honolulu.

Hayes, K. A., R. C. Joshi, S. C. Thiengo, and R. H. Cowie. 2008. Out of South America: Multiple origins of non-native apple snails in Asia. Diversity and Distributions 14: 701-712.

Hayes, K. A., S. C. Thiengo, and R. H. Cowie. 2009. A global phylogeny of apple snails: Gondwanan origin, generic relationships and the influence of outgroup choice (Caenogastropoda: Ampullariidae). Biological Journal of the Linnean Society (in press)

Holland, B. S. and R. H. Cowie. 2006. Dispersal and vicariance in Hawaii: Submarine slumping does not create deep inter-island channels. Journal of Biogeography 33: 2155-2157.

Huey, R. B., G. W. Gilchrist, and A. P. Hendry. 2005. Using invasive species to study evolution: Case studies with Drosophila and salmon. In: D. F. Sax, J. J. Stachowicz, and S. D. Gaines, eds., Species Invasions: Insights into Ecology, Evolution and Biogeography. Sinauer Associates, Sunderland, Massachusetts. Pp. 139-164.

Hutchinson, G. E. 1959. Homage to Santa Rosalia or why are there so many kinds of animals? American Naturalist 93: 145-159.

Iturralde-Vinent, M. A. and R. D. E. MacPhee. 1999. Paleogeography of the Caribbean region: Implications for Cenozoic biogeography. Bulletin of the American Museum of Natural History 238: $1-95$. 
Janzen, D. H. 1967. Why mountain passes are higher in the tropics. American Naturalist 101: 233-249.

Jones, J. S. 1981. An uncensored page of fossil history. Nature 293: 427-428.

Jørgensen, A., T. K. Kristensen, and H. Madsen. 2008. A molecular phylogeny of apple snails (Gastropoda, Caenogastropoda, Ampullariidae) with an emphasis on African species. Zoologica Scripta 37: 245-252.

Joshi, R. C. and L. S. Sebastian. 2006. Global Advances in Ecology and Management of Golden Apple Snails. Philippine Rice Research Institute, Nueva Ecija, Philippine.

Kocher, T. D. 2004. Explosive speciation: The cichlid fish model. Nature 5: 288-298.

Kondoh, M. 2003. Foraging adaptation and the relationship between food-web complexity and stability. Science 299: 1388-1391.

Lindberg, D. R., W. F. Ponder, and G. H. Haszprunar. 2004. The Mollusca: Relationships and patterns from their first half-billion years. In: J. Cracraft, ed., Assembling the Tree of Life. Oxford University Press, Cary, North Carolina. Pp. 252-278.

Louda, S. M., K. R. McKaye, T. D. Kocher, and C. J. Stackhouse. 1984. Activity, dispersion, and size of Lanistes nyassanus and L. solidus (Gastropoda, Ampullariidae) over the depth gradient at Cape Maclear, Lake Malawi, Africa. The Veliger 26: 145-152.

Lundberg, J. G. 1998. The temporal context of the diversification of Neotropical fishes. In: L. R. Malabarba, R. E. Reis, R. P. Vari, Z. M. S. Lucena, and C. A. S. Lucena, eds., Phylogeny and Classification of Neotropical Fishes. Edipucrs, Porto Alegre, Brazil. Pp. 49-68.

McArthur, A. G. and M. G. Harasewych. 2003. Molecular systematics of the major lineages of the Gastropoda. In: C. Lydeard and D. R. Lindberg, eds., Molecular Systematics and Phylogeography of Mollusks. Smithsonian Institution, Washington, D.C. Pp. 140160.

Mandahl-Barth, G. 1954. The freshwater mollusks of Uganda and adjacent territories. Annales du Musée Royal du Congo Belge, Tervuren, $8^{\circ}$, Sciences Zoologiques 32: 1-206.

Mavárez, J., C. Steiner, J.-P. Pointier, and P. Jarne. 2002. Evolutionary history and phylogeography of the schistosome-vector freshwater snail Biomphalaria glabrata based on nuclear and mitochondrial DNA sequences. Heredity 89: 266-271.

Melchor, R. N., J. F. Genise, and S. E. Miquel. 2002. Ichnology, sedimentology and paleontology of Eocene calcareous paleosols from a palustrine sequence, Argentina. Palaios 17: 16-35.

Mittelbach, G. G., D. W. Schemske, H. V. Cornell, A. P. Allen, J. M. Brown, M. B. Bush, S. P. Harrison, A. H. Hurlbert, N. Knowlton, H. A. Lessios, C. M. McCain, A. R. McCune, L. A. McDade, M. A. McPeek, T. J. Near, T. D. Price, R. E. Ricklefs, K. Roy, D. F. Sax, D. Schluter, J. M. Sobel, and M. Turelli. 2007. Evolution and latitudinal diversity gradient: Speciation, extinction and biogeography. Ecology Letters 10: 315-331.

Montoya-Burgos, J. I. 2003. Historical biogeography of the catfish genus Hypostomus (Siluriformes: Loricariidae), with implications on the diversification of Neotropical ichthyofauna. Molecular Ecology 12: 1855-1867.

Nelson, G. 2006. Hawaiian vicariance. Journal of Biogeography 33: 2154-2155.
Ogden, J. C., S. M. Davis, T. K. Barnes, K. J. Jacobs, and J. H. Gentile. 2005. Total system conceptual ecological model. Wetlands 25: 955-979.

Paine, R. T. 1966. Food web complexity and species diversity. American Naturalist 100: 65-75.

Perdices, A., E. Bermingham, A. Montilla, and I. Doadrio. 2002. Evolutionary history of the genus Rhamdia (Teleostei: Pimelodidae) in Central America. Molecular Phylogenetics and Evolution 25: 172-189.

Pimentel, D., R. Zuniga, and D. Morrison. 2005. Update on the environmental and economic costs associated with alien-invasive species in the United States. Ecological Economics 52: 273-288.

Prashad, B. 1925. Revision of the Indian Ampullariidae. Memoirs of the Indian Museum 8: 69-89.

Puth, L. M. and D. M. Post. 2005. Studying invasion: Have we missed the boat? Ecology Letters 8: 715-721.

Rawlings, T. A., K. A. Hayes, R. H. Cowie, and T. M. Collins. 2007. The identity, distribution and impacts of non-native apple snails in the continental United States. BMC Evolutionary Biology 7: 97.

Reed, W. L. and F. J. Janzen. 1999. Natural selection by avian predators on shell size and color of a freshwater snail. Biological Journal of the Linnean Society 67: 331-342.

Ribas, C. C., R. Gaban-Lima, C. Y. Miyaki, and J. Cracraft. 2005. Historical biogeography and diversification within the Neotropical parrot genus Pionopsitta (Aves: Psittacidae). Jounal of Biogeography 32: 1409-1427.

Rohde, K. 1992. Latitudinal gradients in species diversity: The search for the primary cause. Oikos 65: 514-527.

Sax, D. F., J. J. Stachowicz, J. H. Brown, J. F. Bruno, M. N. Dawson, S. D. Gaines, R. K. Grosberg, A. Hastings, R. D. Holt, M. M. Mayfield, M. I. O’Connor, and W. R. Rice. 2007. Ecological and evolutionary insights from species invasions. Trends in Ecology and Evolution 22: 465-471.

Schluter, D. 2001. Ecology and origin of species. Trends in Ecology and Evolution 16: 372-380.

Schultheiß, R., T. Geertz, K. Heiler, and C. Albrecht. 2007. Challenging the biogeographical scenario of diversification of the Ampullariidae (Caenogastropoda) using molecular methods. In: K. Jordaens, N. Van Houtte, J. Van Goethem, and T. Backeljau, eds., Abstracts of the World Congress of Malacology 2007, Antwerp, Belgium. Unitas Malacologica, Antwerp. P. 199.

Scotese, C. R. 2002. PALEOMAP project. Available at http://www. scotese.com 1 July 2007.

Simone L. R. L. 2004. Comparative morphology and phylogeny of representatives of the superfamilies of architaenioglossans and the Annulariidae (Mollusca, Caenogastropoda). Arquivos do Museu Nacional (Rio de Janeiro) 62: 387-504.

Sivasundar, A., E. Bermingham, and G. Ortí. 2001. Population structure and biogeography of migratory freshwater fishes (Prochilodus:Characiformes) in major South American rivers. Molecular Ecology 10: 407-417.

Snyder, N. F. R. and H. A. Snyder. 1971. Defenses of the Florida apple snail Pomacea paludosa. Behaviour 40: 175-215.

Stevens, G. C. 1989. The latitudinal gradient in geographical range: How so many species coexist in the tropics. American Naturalist 133: $240-256$. 
Strong, E. E., O. Gargominy, W. E. Ponder, and P. Bouchet. 2008. Global diversity of gastropods (Gastropoda; Mollusca) in freshwater. Hydrobiologia 595: 149-166.

Tanaka, M. O., A. L. T. Souza, and E .S. Módena. 2006. Habitat structure effect on size selection of snail kites (Rostrhamus sociabilis) and limpkins (Aramus guarauna) when feeding on apple snails (Pomacea spp.). Acta Oecologica 30: 88-96.

Terborgh, J. 1973. On the notion of favorableness in plant ecology. American Naturalist 107: 481-501.

Thieme, M. L., R. Abell, M. L. J. Stiassny, P. Skelton, B. Lehner, G. G. Teugels, E. Dinerstein, A. K. Toham, N. Burgess, and D. Olson. 2005. Freshwater Ecoregions of Africa and Madagascar. A Conservation Assessment. Island Press, Washington, D.C., Covelo, London.

Thiengo, S. C. 1989. On Pomacea sordida (Swainson, 1823) (Prosobranchia, Ampullariidae). Memórias do Instituto Oswaldo Cruz 84: 351-355.

Thiengo, S. C., C. E. Borda, and J. L. Barros Araújo. 1993. On Pomacea canaliculata (Lamarck, 1822) (Mollusca, Pilidae: Ampullariidae). Memórias do Instituto Oswaldo Cruz 88: 67-71.

Thiengo, S. C., K. A. Hayes, A. C. Mattos, M. A. Fernandez, and R. H. Cowie. 2007. South American Ampullariidae: Morphology and taxonomy of the genus Pomacea. III Taller de Biología de Ampullariidae, Tupungato, Argentina, 29 November - 2 December 2007. Abstracts, P. 8.

Tracey, S., J. A. Todd, and D. H. Erwin. 1993. Mollusca: Gastropoda. In: M. J. Benton, ed., The Fossil Record 2. Chapman \& Hall, New York. Pp. 131-167.

van Bruggen, A. C. 1995. Biodiversity of the Mollusca: Time for a new approach. In: A. C. van Bruggen, S. M. Wells, and T. C. M. Kemperman, eds., Biodiversity and Conservation of the Mollusca. Backhuys Publishers, Oegstgeest-Leiden, The Netherlands. Pp. 1-19.

Van Damme, D. 1984. The Freshwater Mollusca of Northern Africa. Dr. W. Junk Publishers, Dordrecht, The Netherlands.

Van Damme, D. and M. Pickford. 1995. The late Cenozoic Ampullariidae (Mollusca, Gastropoda) of the Albertine Rift Valley (Ugandda-Zaire). Hydrobiologia 316: 1-32.

Vermeij, G. J. 1982. Unsuccessful predation and evolution. The American Naturalist 120: 701-720.

Vermeij, G. J. and A. P. Covich 1978. Coevolution of freshwater gastropods and their predators. The American Naturalist 112: 833843.

Via. S. 2002. The ecological genetics of speciation. American Naturalist 159: S1-S7.

Wada, T. and K. Matsukura. 2007. Seasonal changes in cold hardiness of the invasive freshwater apple snail, Pomacea canaliculata (Lamarck) (Gastropoda: Ampullariidae). Malacologia 49: 383-392.

Wallace, A. R. 1852. On the monkeys of the Amazon. Proceedings of the Zoological Society of London 20: 107-110.

Wallace, A. R. 1878. Tropical Nature and Other Essays. Macmillian, London.

Wang, H.-J. 1984. Two Upper Jurassic gastropod opercula in China. Acta Palaeontologica Sinica 23: 369-372.

Wiens, J. J., C. H. Graham, D. S. Moen, S. A. Smith, and T. W. Reeder. 2006. Evolutionary and ecological causes of the latitu- dinal diversity gradient in hylid frogs: Treefrog trees unearth the roots of high tropical diversity. American Naturalist 168: 579-596.

Wright, S., J. Keeling, and L. Gillman. 2006. The road from Santa Rosalia: A faster tempo of evolution in tropical climates. Proceedings of the National Academy of Sciences 103: 7718-7722.

Yoshida, T., S. P. Ellner, L. E. Jones, B. J. M. Bohannan, R. E. Lenski, and N. G. Hairston, Jr. 2007. Cryptic population dynamics: Rapid evolution masks trophic interactions. PLOS Biology 5: e235 doi:10.1371/journal.pbio.0050235.

Submitted: 9 November 2008; accepted: 4 February 2009; final revisions received: 16 March 2009 